\title{
Patterns of Understory Plant Diversity in Response to Transmitted Solar Radiation in a Subtropical Forest
}

\author{
Xiaorong Jia ${ }^{1}$, Runxia Huang ${ }^{1}$, Yi Zhou ${ }^{2}$, Zhiyao Su ${ }^{1}$ * \\ ${ }^{1}$ College of Forestry and Landscape Architecture, South China Agricultural University, Guangzhou 510642, China \\ ${ }^{2}$ Guangdong Academy of Forestry, Guangzhou 510520, China
}

\begin{abstract}
In order to reveal how transmitted solar radiation affects understory plant diversity patterns, we carried out plant census in a subtropical forest in south China. We determined canopy structure and understory gap light regimes using hemispherical photography. The results showed that a total of 206 species and 14489 individuals occur in the understory vegetation of the 2-ha sampling plots. Canopy openness was found to be a good predictor for transmitted direct radiation, diffuse radiation, and total radiation. Indicator species analysis detected a number of indicators to varying canopy openness. Six of these indicator species with significant indicator values are tree seedlings, shrubs, or vine, which are shade-intolerant, or frequently occur in habitats with the greatest canopy openness. Our results demonstrated that understory plant species composition and diversity are affected by transmitted gap light and different species may have varying response to the radiation gradient, which will have implications for using plants from the natural environment in landscaping.
\end{abstract}

\section{Introduction}

Understory plants play a key role in species diversity maintenance, soil and water conservation, and forest community succession. Understory plant species composition and diversity change in response to varying forest canopy structure $[1,2]$. These changes are mainly dependent on the light passing through the canopy of the forest. Plant species adapted to different environmental conditions can exhibit quantitative indication in abundance and distribution frequency. Shrubs, herbs, vines, ferns, and the tree seedlings in the understory can serve as effective indicators of various environmental gradients [3-5], such as solar radiation, soil moisture availability, and topography. Therefore, by studying understory plant diversity patterns and the distribution of transmitted gap light under varied canopy openness, we can determine light requirements of understory plants and detect indicator plant species in response to solar radiation or canopy openness gradient.

Understory gap light regimes are dependent on the forest canopy structure. Canopy structure can be reflected by the canopy openness, which means that when one look upward from under the forest, the percentage of the sky sphere not obstructed by the tree foliages $[6,7,9]$. Canopy adjust understory light by blocking the transmission of solar radiation or by increasing canopy openness to permit greater light transmission. Thus canopy structure has a great impact on the understory light. Understory light transmitted through the canopy involves direct radiation and diffuse radiation. Direct radiation is the light directly passing through the canopy to the understory, while diffuse radiation refers to the light reflected from any orientation within the understory $[8,9]$. In this study, we collected inventory data from plant census and determined canopy structure and understory gap light using hemispherical photography, a short-range remote sensing technology currently widely use in fields of agriculture, forestry, and ecological monitoring $[10,11]$. We aim to reveal the relations of understory plant diversity patterns to canopy structure and understory transmitted radiation, as well as to detect indicator species of various canopy openness or light regimes, which will have significant implications for applying plants from the natural environment in landscaping.

\section{Methods}

\subsection{Study site}

This study was conducted at Deqing Sanchading Nature Reserve $\left(23^{\circ} 24^{\prime} \sim 23^{\circ} 28^{\prime} \mathrm{N}, 111^{\circ} 59^{\prime} \sim 112^{\circ} 03^{\prime} \mathrm{E}\right)$, western Guangdong Province of south China. The study area is hilly and mountainous, with the highest point at $700 \mathrm{~m}$ a.s.l and the lowest at $120 \mathrm{~m}$ a.s.l. The zonal soil types are mainly red soil, with some dark brown and brown soils. The study area has a typical southern subtropical monsoon climate, with an average annual temperature and precipitation of $21.5^{\circ} \mathrm{C}$ and $1502.4 \mathrm{~mm}$, respectively [12]. The dominant families of this area are Gramineae, Adiantaceae, Connaraceae, Rutaceae, Myrsinaceae, Araliaceae, and Lauraceae.

\subsection{Data collection}

In order to study the patterns of understory plant diversity in response to solar radiation, a 2-ha plot was set up within the forest vegetation of Sanchading Nature Reserve. The plot was further divided into 200 subplots, each $100 \mathrm{~m}^{2}$. Dominant canopy trees and all the understory plants were censused and recorded, together with habit designation for each plant, such as tree seedling, shrub, forb, graminoid, vine, and fern. In the center of each subplot, a hemispherical photograph was taken using a Nikon CoolPix 4500 digital camera adapted with a Nikkor FC-E8 Fisheye converter. The Camera was placed at $1.65 \mathrm{~m}$ from the ground on a tripod, levelling and looking upward to the sky.

All the hemispherical images were processed and analyzed using Gap Light Analyzer 2.0 image processing software [13]. Latitude and longitude were entered when 
setting the site parameters as required. Canopy Openness, Transmitted Direct Solar Radiation, Transmitted Diffuse Solar Radiation, and Transmitted Total Solar Radiation were obtained from the image analysis.

\subsection{Statistical analysis}

Diversity indexes computation and indicator species analysis were performed using PC-ORD 6.0, while correlation analysis was carried out using Statistica 6.0.

\section{Results and analysis}

\subsection{Species composition and diversity}

A total of 206 species and 14489 individuals occurred in the understory vegetation of the 2-ha sampling plots. Forty-one of these species had an abundance $\geqslant 90$, including Sinobambusa tootsik var. Laeta, Adiantum flabellulatum, Rourea microphylla, Evodia lepta, Rourea minor, and Ardisia quinquegona. The maximum abundance reached 1215 individuals, while the average frequency per species ranged from 10 to 153 subplots, and the relative abundance from 0.620 to 8.390 . The maximum frequency was 7.00 and the minimum was 0.46 , while the Importance Value had the maximum of 7.19 , with the minimum of 0.59 (Table 1).

In each $100-\mathrm{m}^{2}$ subplot, the number of individuals ranged from 25 to 266, with a mean value of 72 and the

coefficient of variation (CV) 41.91. The number of species ranged from 8 to 34 , with a mean value of 21 and

CV 22.71. The Pielou's evenness ranged from 0.54 to 0.97 , with a mean value of 0.85 and CV 10.13. ShannonWiener diversity index ranged from 1.19 to 3.32 , with a

Table 1. Dominant species with an abundance $\geqslant 90$ in the forest understory.

\begin{tabular}{|l|c|c|c|c|c|}
\hline \multicolumn{1}{|c|}{ Species } & $\mathrm{N}$ & $\mathrm{F}$ & $\mathrm{RA}$ & $\mathrm{RF}$ & I.V.(\%) \\
\hline $\begin{array}{l}\text { Sinobambusa tootsik } \\
\text { var. laeta }\end{array}$ & 1215 & 88 & 8.39 & 4.03 & 6.21 \\
\hline Adiantum flabellulatum & 1068 & 153 & 7.37 & 7.00 & 7.19 \\
\hline Rourea microphylla & 710 & 75 & 4.90 & 3.43 & 4.17 \\
\hline Evodia lepta & 542 & 66 & 3.74 & 3.02 & 3.38 \\
\hline Rourea minor & 528 & 104 & 3.64 & 4.76 & 4.20 \\
\hline Ardisia quinquegona & 509 & 109 & 3.51 & 4.99 & 4.25 \\
\hline Schefflera octophylla & 463 & 53 & 3.20 & 2.43 & 2.81 \\
\hline Cryptocarya concinna & 406 & 86 & 2.80 & 3.94 & 3.37 \\
\hline Tetracera asiatica & 405 & 49 & 2.80 & 2.24 & 2.52 \\
\hline Calamus rhabdocladus & 371 & 54 & 2.56 & 2.47 & 2.52 \\
\hline Lygodium flexuosum & 367 & 57 & 2.53 & 2.61 & 2.57 \\
\hline Dalbergia hancei & 367 & 37 & 2.53 & 1.69 & 2.11 \\
\hline Symplocos adenophylla & 329 & 40 & 2.27 & 1.83 & 2.05 \\
\hline Mussaenda pubescens & 292 & 48 & 2.02 & 2.20 & 2.11 \\
\hline Gahnia tristis & 292 & 44 & 2.02 & 2.01 & 2.01 \\
\hline Lophatherum gracile & 266 & 43 & 1.84 & 1.97 & 1.90 \\
\hline Millettia dielsiana & 262 & 41 & 1.81 & 1.88 & 1.84 \\
\hline Psychotria rubra & 240 & 59 & 1.66 & 2.70 & 2.18 \\
\hline
\end{tabular}

\begin{tabular}{|l|c|c|c|c|c|}
\hline Blechnum orientale & 209 & 36 & 1.44 & 1.65 & 1.55 \\
\hline Smilax glabra & 208 & 27 & 1.44 & 1.24 & 1.34 \\
\hline Pithecellobium lucidum & 194 & 37 & 1.34 & 1.69 & 1.52 \\
\hline $\begin{array}{l}\text { Lithocarpus } \\
\text { longanoides }\end{array}$ & 177 & 38 & 1.22 & 1.74 & 1.48 \\
\hline Meliosma thorelii & 162 & 24 & 1.12 & 1.10 & 1.11 \\
\hline Machilus chinensis & 155 & 30 & 1.07 & 1.37 & 1.22 \\
\hline $\begin{array}{l}\text { Calophyllum } \\
\text { membranaceum }\end{array}$ & 152 & 21 & 1.05 & 0.96 & 1.01 \\
\hline $\begin{array}{l}\text { Dicranopteris } \\
\text { dichotoma }\end{array}$ & 149 & 19 & 1.03 & 0.87 & 0.95 \\
\hline Thysanolaena maxima & 142 & 32 & 0.98 & 1.46 & 1.22 \\
\hline Embelia laeta & 141 & 11 & 0.97 & 0.50 & 0.74 \\
\hline Syzygium rehderianum & 114 & 25 & 0.79 & 1.14 & 0.97 \\
\hline $\begin{array}{l}\text { Sinosideroxylon } \\
\text { wightianum }\end{array}$ & 113 & 10 & 0.78 & 0.46 & 0.62 \\
\hline Sapium discolor & 106 & 16 & 0.73 & 0.73 & 0.73 \\
\hline Lithocarpus corneus & 105 & 17 & 0.72 & 0.78 & 0.75 \\
\hline Diospyros eriantha & 104 & 18 & 0.72 & 0.82 & 0.77 \\
\hline Sarcandra glabra & 103 & 23 & 0.71 & 1.05 & 0.88 \\
\hline Glochidion eriocarpum & 103 & 14 & 0.71 & 0.64 & 0.68 \\
\hline Canarium pimela & 99 & 14 & 0.68 & 0.64 & 0.66 \\
\hline Lithocarpus glaber & 98 & 19 & 0.68 & 0.87 & 0.77 \\
\hline Smilax hypoglauca & 97 & 17 & 0.67 & 0.78 & 0.72 \\
\hline Lithocarpus uvariifolius & 91 & 12 & 0.63 & 0.55 & 0.59 \\
\hline Woodwardia japonica & 90 & 16 & 0.62 & 0.73 & 0.68 \\
\hline Melastoma sanguineum & 90 & 15 & 0.62 & 0.69 & 0.65 \\
\hline
\end{tabular}

Notes: $\mathrm{N}=$ abundance or number of individuals; $\mathrm{F}=$ Frequency or plot occurrence; $\mathrm{RA}=$ relative abundance; $\mathrm{RF}=$ relative frequency; I.V. = importance value

mean value of 2.57 and CV 14.91. Simpson's diversity index ranged from 0.58 to 0.96 , with a mean value of 0.88 and CV 6.91 (Table 2). Diversity metrics were also calculated for the entire community, as listed in Table 2.

Table 2. Variation in species composition and diversity.

\begin{tabular}{|l|c|c|c|c|c|}
\hline Attribute & $\mathrm{N}$ & $\mathrm{S}$ & $\mathrm{E}$ & $\mathrm{H}^{\prime}$ & $\mathrm{D}$ \\
\hline Community-wide & 14489 & 206 & 0.78 & 4.13 & 0.97 \\
\hline Across plots & & & & & \\
\hline Mean & 72 & 21 & 0.85 & 2.57 & 0.88 \\
\hline SD & 30.36 & 4.73 & 0.09 & 0.38 & 0.06 \\
\hline Max & 266 & 34 & 0.97 & 3.32 & 0.96 \\
\hline Min & 25 & 8 & 0.54 & 1.19 & 0.58 \\
\hline CV(\%) & 41.91 & 22.71 & 10.13 & 14.91 & 6.91 \\
\hline
\end{tabular}

Notes: 1) $\mathrm{N}=$ number of individuals; $\mathrm{S}=$ Number of species; $\mathrm{E}$ = Pielou' s evenness; H' = Shannon-Wiener diversity index; $\mathrm{D}=$ Simpson' s diversity index. 2) the mean values of individual number and species number have been rounded.

\subsection{Canopy structure and gap light}

Correlation analysis showed that canopy openness significantly and positively correlated with transmitted 
direct radiation (Figure 1), diffuse radiation (Figure 2), and total radiation (Figure 3 ), thus being a good predictor for understory gap light regimes.

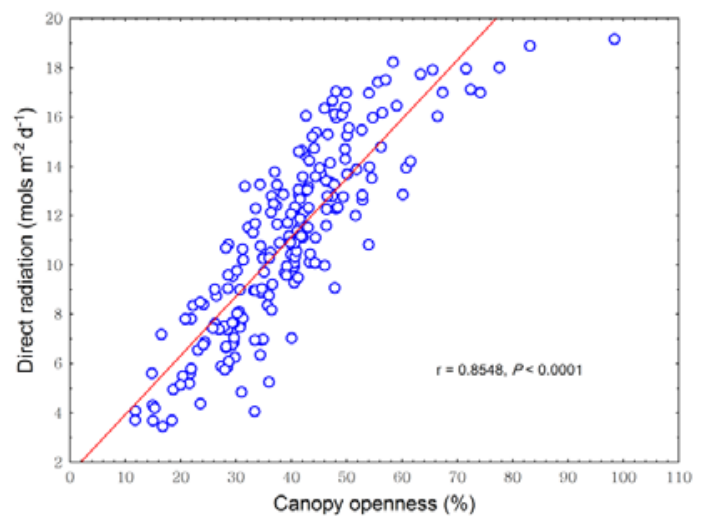

Figure 1. Relation of canopy openness to transmitted direct radiation.

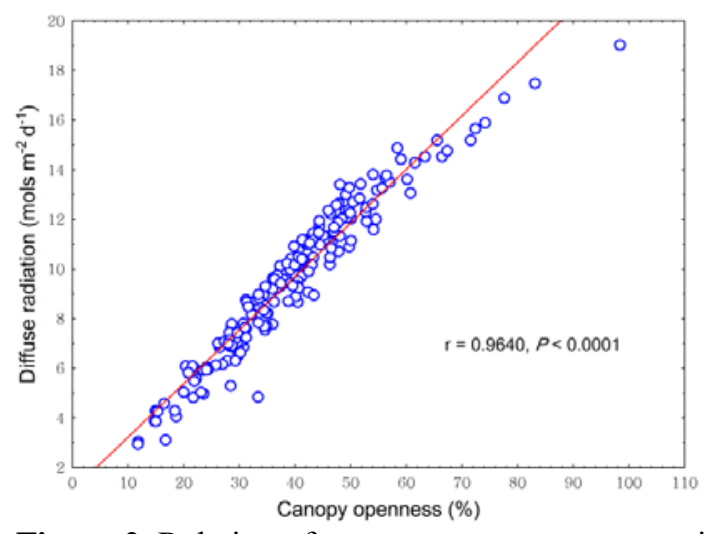

Figure 2. Relation of canopy openness to transmitted diffuse radiation.

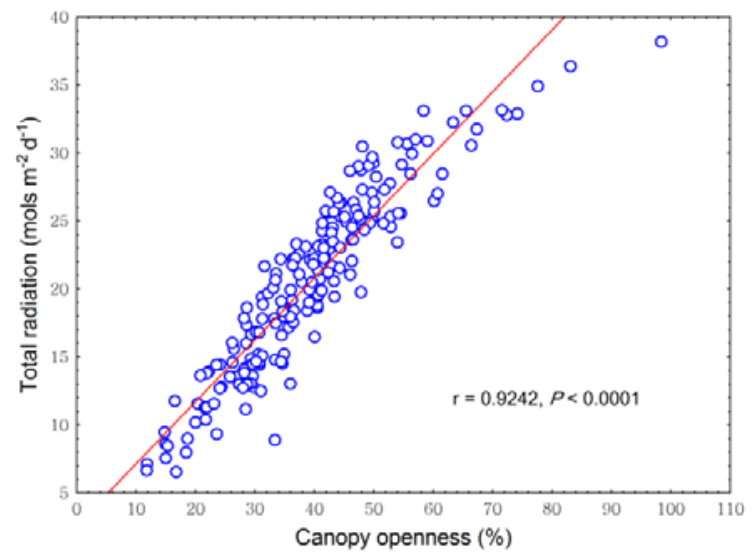

Figure 3. Relation of canopy openness to transmitted total radiation.

A greater canopy openness will permit more light transmitted from the canopy to the understory. Judging by the correlation coefficient, the perfect correlation was found between canopy openness and transmitted diffuse radiation.

\subsection{Indicator species to gap gradient}

A total of seventeen species with an indicator value $>15$ were potential indicator species of canopy structure
(Table 3). Six of these potential indicator species with significant indicator value, i.e., Sapium discolor, Dicranopteris, Smilax china, Itea chinensis, Breynia fruticosa, and Cyclea racemosa, were exclusively related to the Class 3 canopy openness, indicating that they are shade-intolerant or sun plants.

\section{Discussion}

A significant positive correlation existed between canopy openness and understory light, indicating that understory gap light regimes varied with canopy openness. The perfect correlation was found between canopy openness and transmitted diffuse radiation, indicating that direct radiation is largely obstructed by the canopy. The difference in the shapes and sizes, and the uneven distribution of canopy gaps all affect the interception of solar radiation. Our study focuses on the relationship between solar radiation and understory vegetation, and we determine canopy structure and transmitted gap light, including direct radiation, diffuse radiation, and total radiation, using hemispherical photography, a novel photogrammetric approach. Studies have shown that hemispherical photography is a fast and accurate method for determining the canopy structure and understory gap light indicators, and applicably explaining the growth and distribution patterns of understory vegetation [14]. Indicator species analysis, on the other hand, is a sensitive approach for investigating species-habitat relationship, which will find increasingly wide application in many fields such as agriculture, biodiversity conservation, forest resource management, and ecological monitoring. Using a combination of these methods, we completed our investigation and the relations of understory plant diversity patterns in response to canopy structure and solar radiation were revealed.

Table 3. Indicator species with an indicator value $\geq 15$ in relation to different canopy openness.

\begin{tabular}{|l|c|c|c|c|}
\hline Species & Habit & $\begin{array}{c}\text { Canopy } \\
\text { Openness }\end{array}$ & $\begin{array}{c}\text { Indicator } \\
\text { value }\end{array}$ & $P$ \\
\hline $\begin{array}{l}\text { Sapium } \\
\text { discolor }\end{array}$ & $\begin{array}{c}\text { Tree } \\
\text { Seedling }\end{array}$ & 3 & 46.3 & 0.0001 \\
\hline $\begin{array}{l}\text { Dicranopteris } \\
\text { dichotoma }\end{array}$ & Fern & 3 & 27.6 & 0.0091 \\
\hline $\begin{array}{l}\text { Meliosma } \\
\text { thorelii }\end{array}$ & $\begin{array}{c}\text { Tree } \\
\text { Seedling }\end{array}$ & 2 & 24.1 & 0.1036 \\
\hline Smilax china & Shrub & 3 & 22.4 & 0.0004 \\
\hline $\begin{array}{l}\text { Pithecellobium } \\
\text { lucidum }\end{array}$ & $\begin{array}{c}\text { Tree } \\
\text { Seedling }\end{array}$ & 1 & 22.2 & 0.2739 \\
\hline $\begin{array}{l}\text { Itea chinensis } \\
\text { Sree } \\
\text { Seedling }\end{array}$ & Shrub & 3 & 22.1 & 0.0302 \\
\hline $\begin{array}{l}\text { Breynia } \\
\text { fruticosa }\end{array}$ & $\begin{array}{c}\text { Tree } \\
\text { Lithocarpus } \\
\text { longanoides }\end{array}$ & 2 & 20.6 & 0.03019 \\
\hline $\begin{array}{l}\text { Calophyllum } \\
\text { membranaceum }\end{array}$ & Shrub & 1 & 19.6 & 0.0561 \\
\hline $\begin{array}{l}\text { Melastoma } \\
\text { sanguineum }\end{array}$ & Shrub & 3 & 19.2 & 0.0565 \\
\hline Embelia laeta & Shrub & 2 & 18.5 & 0.1427 \\
\hline
\end{tabular}




\begin{tabular}{|c|c|c|c|c|}
\hline $\begin{array}{l}\text { Machilus } \\
\text { chinensis }\end{array}$ & $\begin{array}{c}\text { Tree } \\
\text { Seedling }\end{array}$ & 2 & 18.1 & 0.3594 \\
\hline $\begin{array}{l}\text { Glochidion } \\
\text { eriocarpum }\end{array}$ & Shrub & 3 & 17.9 & 0.0809 \\
\hline $\begin{array}{l}\text { Cyclea } \\
\text { racemosa }\end{array}$ & Vine & 3 & 17.7 & 0.0129 \\
\hline Lindera chunii & $\begin{array}{c}\text { Tree } \\
\text { Seedling }\end{array}$ & 1 & 17.1 & 0.0652 \\
\hline $\begin{array}{l}\text { Thysanolaena } \\
\text { maxima }\end{array}$ & Graminoid & 3 & 16.9 & 0.2845 \\
\hline $\begin{array}{l}\text { Sarcandra } \\
\text { glabra }\end{array}$ & Forb & 2 & 15.6 & 0.1208 \\
\hline
\end{tabular}

Note: Canopy openness (CO) gradient: $1: \mathrm{CO} \leqslant 30 \% ; 2: 30 \%<$ $\mathrm{CO} \leqslant 60 \% ; 3: \mathrm{CO}>60 \%$.

Our results demonstrated that understory plant species composition and diversity are affected by transmitted gap light. Different species may have various responses to the radiation gradient, including transmitted direct radiation and diffuse radiation. Indicator species analysis revealed that six of these indicator species with significant indicator values are shade-intolerant, or frequently occur in the subplots with the greatest canopy openness.

\section{Acknowledgements}

The authors thank Dr. Zhenkui Li for his help in plant identification. This study is funded by a grant from Guangdong Department of Science and Technology (Grant No. 2013B020305008).

\section{References}

[1] E.K. Dodson., D.W. Peterson and R.J. Harrod, Understory vegetation response to thinning and burning restoration treatments in dry conifer forests of the eastern Cascades, USA. Forest Ecol. Manag. 255, 3130 (2008)

[2] R.B. Wayman, and M. North, Initial response of a mixed-conifer understory plant community to burning and thinning restoration treatments. Forest Ecol. Manag. 239, 32 (2007)

[3] C.F. Liu, Z.N. Wang, K.N. HE, Change of soil water content and light of several plantations at Loess Plateau semi-arid area and its effect on forest stand. J West China For. Sci. 33,34 (2004) (in Chinese)

[4] L.X. Yuan, N.Y. Long, Z.Q. Xie, et al, Study on modern pollution source and Bio-Indicator in NYAlesund, Arctic. Chinese J Polar Res. 18, 9 (2006) (in Chinese)

[5] S. Jacobson, and L. Gustafsson, Effects on ground vegetation of the application of wood ash to a Swedish Scots pine stand. Basic and Applied Ecol., 2, 233 (2001)

[6] J.J. Zhu., T. Matsuzaki., F Q Lee., et al., Effect of gap size created by thinning on seedling emergency, survival and establishment in a coastal pine forest. Forest Ecol. Manag, 182, 339 (2003)

[7] G.Z. Li, H.X. Wang, J.J. Zhu, Monthly Changes of Leaf Area Index and Canopy Openness of Larixolgensis in Mountainous Regions in East
Liaoning Province. J Northeast Forestry Univ. 37, 20 (2009) (in Chinese)

[8] L.L. Hu, J.J. Zhu, J.S. Li, Review s on methods of measuring light intensities within forest gaps. Acta Ecol. Sinica. 29, 5056 (2009) (in Chinese)

[9] Y.D. Ou, Z.Y. Su, Dynamics of canopy structure and understory light in montane evergreen broadleaved forest following a natural disturbance in North Guangdong. Acta Ecol. Sinica. 32, 5637 (2012) (in Chinese)

[10]A.F. Souza, and F.R. Martins, Spatial Variation and Dynamics of Flooding, Canopy Openness, and Structure in a Neotropical Swamp Forest. Plant Ecol., 180, 161 (2005)

[11]C. Jeffry., Jr. Boutet and F.J. Weishampel. Spatial pattern analysis of pre- and post-hurricane forest canopy structure in North Carolina, USA. Landscape Ecol., 18, 553 (2003)

[12]Z. Y. Su, X.D. Ke, and S.J. Zhang, Vascular plants as indicators of organic carbon gradient in subtropical forested soils. Pol. J. Environ. Stud., 21,1393 (2012)

[13]I. Jonckheere., S. Fleck., K. Nackaerts., et al., Review of methods for in situ leaf area index determination. Agric. and Forest Meteor., 121, 19 (2004)

[14]Z.Y. Su, X.R. Jia, D.D. Xie, et al., Determination of canopy structural parameters in an urban forest stand using hemispherical photography. J South China Agric. Univ. 28,65 (2007) (in Chinese) 